\title{
Genotoxic Effect of Ground Water Salts rich in Fluoride
}

\author{
Om Prakash Chaurasia*, Chanda Kumari, Ankita, and Sangita \\ Cytogenetic Laboratory, P.G. Department of Zoology, T.M. Bhagalpur University, Bhagalpur 812007, India
}

Received September 11, 2006; accepted January 31, 2007

\begin{abstract}
Summary Non-permissible concentration of fluoride salts in ground water induces various anomalies in human beings. Bhagalpur city's ground water contains 1-2 ppm of fluoride. Its genotoxic effects were assessed in Swiss albino mice Mus Musculus. 25\% (50 mg/l) and 50\% (100 mg/l) concentrations were found to increase the frequency of abnormal cells by 10.33 and $19.33 \%$ and chromosome abnormalities by 10.33 and $20.00 \%$ in bone marrow cells. The increase in frequency of chromosome anomaly was mainly due to significant increase in individual type, viz. chromatid breaks, gaps and acentric fragments. The effect is dose dependent. Fluoride salts present in the ground water might have interfered the phagocytosis and produce oxygen free reactive radicals that attack the nucleophilic sites of the DNA leading to the loss of important gene segments responsible for cell growth and the ageing.
\end{abstract}

Key words Ground water, Fluoride, Genotoxicity, Bone marrow cells.

The unplanned and uncontrolled extraction of ground water has disturbed the hydrological balance resulting rapid depletion of water table as well as deterioration of water quality. Non permissible concentration of fluoride and nitrate in ground water, makes it unfit without treatment.

The fluoride ranging from 0.7 to $4.5 \mathrm{ppm}$ induces various anomalies in human such as dental fluorasis, leading to brown decaying teeth and bone disorders such as skeletal fluorasis, Osteoporosis and arthritic pains (http://www.greenfacts.Org/fluoride/fluorides-2/06-effects-environment.htm). Young men are bent over and crippled with pain in their joints and hips. Premature hardening of arteries, loss of appetite and sex drive by age of 30 was resulted. The skin was wrinkled and they look 60 years old at the age of 30 to 40 . Premature ageing was the overall effect of fluoride. The acceleration of ageing process occurred at the biochemical level by means of enzyme inhibition, collagen breakdown and disruption of immune system by inhibiting the migration rate of WBC cells to the infected area and genetic damages (Dunipace et al. 1989).

It also interferes with phagocytosis and induces release of super oxide free radicals which damages the body leading to further acceleration of ageing process (Yiamouyiannis and Gerald 1993).

The fluoride induces cancer and about 61,000 cancer death in USA resulted from fluoridation each year. Fluoride is more poisonous than lead and slightly less poisonous than arsenic. The rate of stillborn miscarriages by 4 months is extremely high in fluoride rich prone areas. It also causes nausea, bloody vomit, faintness, stomach cramps, tremors, skin rash, weight loss, constipation, aching bones etc. (Yiamouyiannis and Gerald 1993).

Bhagalpur city is located on the South bank of river Ganga at $87^{\circ} 02^{\prime} \mathrm{N}$ lattitude and $25^{\circ} 15^{\prime} \mathrm{E}$ longitude. Ground water contains 1-2 ppm fluoride and the people of the city commonly suffer from dental fluorasis, joint pains and osteoporosis. Thus, the harmful effect of fluoride is a global problem (http://www.fao.org/docrep/W2598E/W2598e 04.htm, 6/22/2005). Its genotoxic effects were poorly known (Bhunya 1987, Mohammed and Chandler 1982, Glleva 1975, Voroshilin 1975)

*Corresponding author, e-mail: om_zoology@yahoo.co.in 
Table 1. The frequency $(\% \pm \mathrm{SE})$ of abnormal cells and chromosomal abnormalities in bone marrow cells after treatment with salts present in ground water

\begin{tabular}{|c|c|c|c|c|c|c|c|c|c|}
\hline \multirow{3}{*}{ Treatment } & \multirow{2}{*}{\multicolumn{2}{|c|}{ No. of abnormal cells }} & & \multicolumn{6}{|c|}{ Chromosomal abnormalities } \\
\hline & & & \multicolumn{7}{|c|}{ Individual type } \\
\hline & No. & $\% \pm \mathrm{SE}$ & $\mathrm{Ctb}$ & $\mathrm{Ctg}$ & $\mathrm{AF}$ & MF & $\begin{array}{l}\text { Centric } \\
\text { fusion }\end{array}$ & $\begin{array}{l}\text { Total } \\
\text { No. }\end{array}$ & $\% \pm \mathrm{SE}$ \\
\hline Control & 15 & $5 \pm 1.28$ & 2 & 2 & - & 1 & 2 & 7 & $2.33 \pm 0.87$ \\
\hline $25 \%$ & 46 & $15.33 \pm 2.24 *$ & 30 & - & - & 11 & 1 & 42 & $14.00 \pm 2.14 *$ \\
\hline $50 \%$ & 73 & $24.33 \pm 2.83^{*}$ & 50 & - & - & 18 & - & 68 & $22.66 \pm 2.73 *$ \\
\hline
\end{tabular}

\begin{tabular}{|c|c|c|c|c|c|c|}
\hline \multirow{3}{*}{ Treatment } & \multicolumn{4}{|c|}{ Chromosomal abnormalities } & \multirow{2}{*}{\multicolumn{2}{|c|}{ Grand total }} \\
\hline & \multirow{2}{*}{$\begin{array}{l}\text { Total } \\
\text { Aneu }\end{array}$} & \multirow{2}{*}{ Poly } & \multicolumn{2}{|c|}{ Gross type } & & \\
\hline & & & No. & $\% \pm \mathrm{SE}$ & No. & $\% \pm \mathrm{SE}$ \\
\hline Control & 2 & 6 & 8 & $2.66 \pm 0.93$ & 15 & $5 \pm 1.28$ \\
\hline $25 \%$ & 4 & - & 4 & $1.33 \pm 0.66$ & 46 & $15.33 \pm 2.24 *$ \\
\hline $50 \%$ & 4 & 3 & 7 & $2.33 \pm 0.87$ & 75 & $25 \pm 2.87 *$ \\
\hline
\end{tabular}

* Indicate significant value at $5 \%$ level in comparison to the control value.

and need to be investigated. In the present investigation an attempt has been made to evalute the genotoxicity of ground water salts rich with fluoride in a laboratory mammal.

\section{Materials and methods}

Experiments were performed on Swiss albino mice, Mus musculus, colony supplied from Central Drug Research Institute (CDRI) Lucknow, India and reared in our department. The ground water was collected from southern area of Bhagalpur city. After evaporation of water, $200 \mathrm{mg}$ of salts were collected from 11 of water. $50 \%(100 \mathrm{mg} / \mathrm{l})$ and $25 \%(50 \mathrm{mg} / \mathrm{l})$ solutions were prepared from collected salts by dissolving it with double distilled water (ddw). 6-8 weeks old mice were fed orally with each concentration separately/1 ml/day/mouse for 15 consecutive days. Altogether 6 mice were taken for each treatment and control group. The control group of mice was fed only with the same amount of double distilled water $(\mathrm{ddw})$. Both treated and control groups of mice were sacrificed immediately after completion of treatment i.e. on the 16th day. Slides from bone marrow were prepared by colchicine-hypotonic-aceto alcohol-flame drying-Giemsa staining technique (Preston et al. 1987). 300 well spread randomly selected metaphases/20 metaphase plates per slide were screened. Number of abnormal cells and chromosomal abnormalities were recorded. The data so obtained were calculated and interpreted.

\section{Results and discussion}

Among 300 metaphase plates, the frequency of abnormal cells were increased by 10.33 and $19.33 \%$ while the chromosomal abnormalities were increased by $10.33 \%$ and $20.00 \%$ upon $25 \%$ and $50 \%$ treatment, respectively, in comparison to the control value (Table 1). The abnormal cells and chromosomal abnormalities were increased with the increase of concentration/dose. Thus, the 


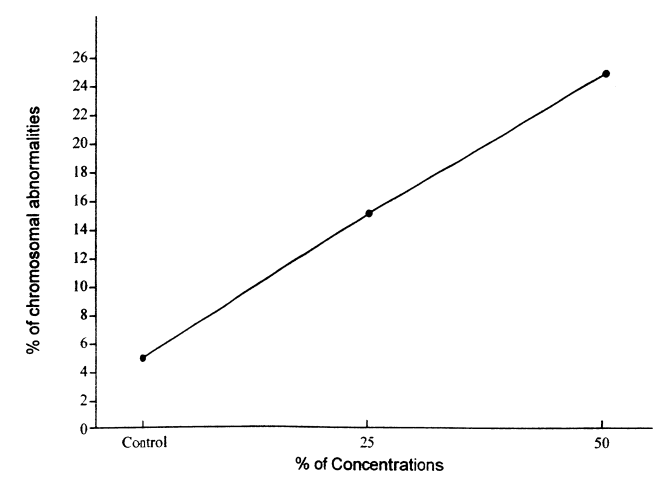

Fig. 1. A dose dependent genotoxic effect on mice after treatment with salts present in ground water.



Fig. 2. A comparison of gross and individual changes upon treatment with salts present in ground water on bone marrow cells of mice.
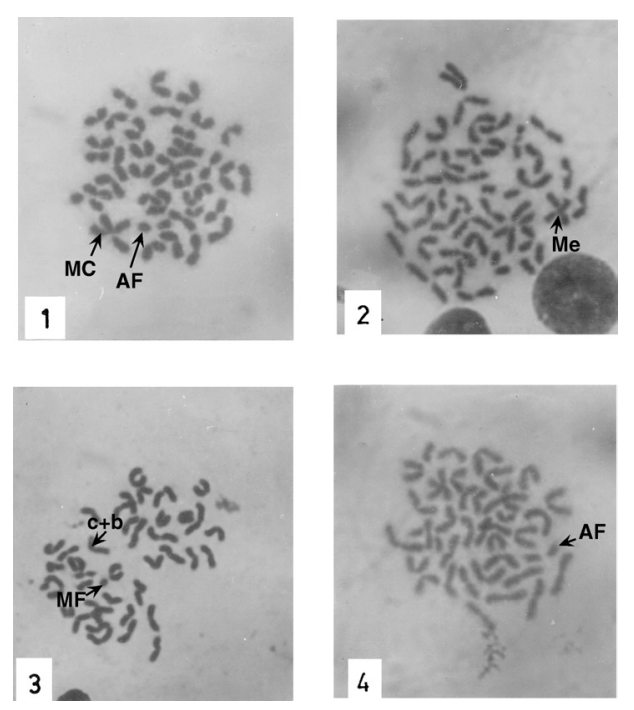

Plate 1. Abnormal cells showing chromosomal abnormalities: 1. Acentric fragment (AF) and metacentric chromosome (MC). 2. Metacentric chromosome (MC. 3. Chromatid break (ctb) and minute fragment (MF).

effect is of concentration/dose dependent. (Fig. 1). Both gross and individual types of abnormalities were observed. The gross abnormalities were increased by $1.33 \%$ and $2.33 \%$, while individual types by $14.00 \%$ and $22.66 \%$ upon $25 \%$ and $50 \%$ treatment, respectively, in comparison to their control (Fig. 2). The increase

of chromosome abnormalities was due to a significant increase of individual type. Aneuploidy, polyploidy, centric fusion were the most common among the gross type while chromatid breaks, acentric and minute fragments of unknown origin were the most common among the individual type (Plate 1). The frequency of acentric and minute fragment was drastically increased. This might occur due to the deletion of telomeric end of chromosomes.

From previous and present studies it becomes clear that ground water salts rich with fluoride induces genetic damages by dose dependent manner. The exact mechanism cannot be pinpointed because salts rich with fluoride interfere a number of physiological process. However, it interferes the phagocytosis and induces to produce super oxide free reactive radicals and ions that attack the nucleophilic sites of DNA leading to break in chromosomes (Yiamouyiannis and Gerald 1993, Chaurasia et al. 2005). It may also interfere with DNA repair enzyme system. The unrepaired DNA damage responsible for the control of cell growth can lead to tumours and/or cancer (Burk and Yiamouyiannis, Gerald 1993) and once it occurs in a sperm or an egg cells, the damage will be repeated in every cells of offspring's body and will lead to a birth defect (Yiamouyiannis and Gerald 1993). In our investigation, the incidence of acentric and minute fragment was very high. The deletion of such important telomeric gene segments, might be resulted to induce cancer/tumours and ageing. 


\section{References}

Agricultural water pollution 2005. Chapter 1, P.P 1 of 19 (http://www.fao.org/docrep/W2598E/W2598 e 0.4 htm)$6 / 22 / 2005$.

Bhunya, S. P. 1987. Genotoxic effect of an environmental pollutants, sodium fluoride in mammalian in vivo test system. Caryologia 40: 79-87.

Chaurasia, O. P, Kumar, A. and Kumari, M. 2005. Genotoxic effect of silk dyeing wastes in bone marrow cells of mice, Mus musculus. Cytologia 70: 381-384.

Dunipace, A. J., Zhang, W., Noblitt, T. W., Li, Y. and Stookey, G. K. 1989. Genotoxic evaluation of chronic fluoride exposure; Micronucleus and Sperm Morphology Studies.

Glleva, E. A. 1975. The mutagenic activity of inorganic fluorine compounds. Fluoride 8: 47-50.

Green facts 2005. Scientific Facts on Fluoride; Summary and Details. Fluoride(6), P.P 1 of 3 (http://www.greenfacts.org/fluoride/fluorides-2/06-effects-environment.htm.

Mohammed, A. H. and Chandler, M. E. 1982. Cytological effects of sodium fluoride on mice. Fluoride 15: 110-118.

Voroshillin, S. I. 1975. Mutagenic effect of hydrogen fluoride on animals. Tsltol Genet 9: 42-44.

Wu-Dq, Wuy 1995. Micronucleus and sister chromatid exchange frequency in Endemic Fluorosis. Fluoride 28: $125-127$. nttp://www.fluoride alert-org/health/ cancer/mutagen.html.

Yiamouyiannis, J. and Gerald, J. 1993. The ageing factor; Fluoride and Cancer, Fluoride-Health Action Press, 1993. 